\title{
Sero-Prevalence of Hepatitis B and Hepatitis C Virue Co-Infection among Pregnant Women in Nigeria
}

\author{
A.J Esan ${ }^{1, *}$, C.T.Omisakin ${ }^{1}$, T.Ojo-Bola ${ }^{2}$, M.F Owoseni ${ }^{1}$, K.A Fasakin ${ }^{1}$, A.A Ogunleye ${ }^{3}$ \\ ${ }^{1}$ Hematology Department, Federal medical Centre, Ido-Ekiti, Nigeria \\ ${ }^{2}$ Medical Microbiology Department, Federal Medical Centre, Ido-Ekiti, Nigeria \\ ${ }^{3}$ Ondo State General Hospital, Okitipupa, Nigeria \\ *Corresponding author: ayodelejacob4u@gmail.com; ayodelejacob4u@yahoo.com
}

Received November 25, 2013; Revised January 18, 2014; Accepted February 09, 2014

\begin{abstract}
This study was carried out to determine sero-prevalence of hepatitis B and hepatitis $C$ virus co-infection among pregnant women. Viral hepatitis during pregnancy is associated with high risk of maternal complications; infections with Hepatitis B virus (HBV) or the Hepatitis C virus (HCV) are public health problems. Worldwide, there are about 350 million HBV carriers and 130 to 170 million people infected with HCV. The presence of HBV and HCV was determined using third-generation enzyme immunoassay (EIA), reactive samples were further confirmed using enzyme linked immune sorbent assay (ELISA) (Bio-Rad, France). Age group 26-30 and 31-35 had highest frequency of 240 (36.98\%) and 206 (31.74\%) respectively in HBV and HCV. Sero prevalence of HBV and HCV were 44 (6.78\%) and 9 (1.39\%) respectively. Prevalence of HBV and HCV co-infection was 1 (0.15\%) in age group 31-35. Proper management of maternal hepatitis during the prenatal phase ensures better outcomes in the infant, therefore screening of pregnant women for hepatitis B and C virus are necessary in order to identify those neonates at risk of transmission.
\end{abstract}

Keywords: Hepatitis B virus, Hepatitis C virus, transmission

Cite This Article: A.J Esan, C.T.Omisakin, T.Ojo-Bola, M.F Owoseni, K.A Fasakin, and A.A Ogunleye, "Sero-Prevalence of Hepatitis B and Hepatitis C Virue Co-Infection among Pregnant Women in Nigeria." American Journal of Biomedical Research, vol. 2, no. 1 (2014): 11-15. doi: 10.12691/ajbr-2-1-3.

\section{Introduction}

Viral hepatitis is a life-threatening liver disease, caused by hepatitis $\mathrm{B}$ and $\mathrm{C}$ virus, and is a major public health problem, particularly in developing countries [31,51]. The prevalence of $\mathrm{HBV}$ and $\mathrm{HCV}$ in a population can be predicted by risk factors associated with the transmission of infection such as injections, blood products transfusion, surgical procedures, body tattooing, occupational injury, sexual and vertical transmission $[1,3,41]$ many infected individuals deny history of any of these risks so that the likely source remains unidentified in some subjects [61] however, the prevalence varies from area to area and population to population due to variability in ethnicity and socioeconomic conditions [31,51]. Viral hepatitis is the inflammation of the liver caused by infection with the hepatitis viruses; it can also be due to toxins (notably alcohol, certain medications and plants), other infections and autoimmune diseases [4]. Viral hepatitis during pregnancy is associated with high risk of maternal complications. Infections with the Hepatitis B virus (HBV) or the Hepatitis $\mathrm{C}$ virus (HCV) are public health problems and are highly endemic in the sub-Saharan Africa [36,37]. Worldwide, there are about 350 million HBV carriers [28] and 130 to 170 million people infected with HCV [74]. $\mathrm{HBV}$ and HCV infections are a major cause of morbidity and mortality. Hepatitis B virus has a circular genome of partially double-stranded DNA. The virus is transmitted through infected blood, sexually and vertically (mother to child) in the perinatal period. Perinatal transmission is the most common mode of HBV transmission worldwide [68]. The Hepatitis B surface antigen (HBsAg) is the serologic hallmark of HBV infection, whilst the soluble extractable protein, the Hepatitis e antigen (HBeAg) is a marker for the highly infectious state. Chronic infection is defined by the presence of HBsAg for more than 6 months. Without immunization, up to $90 \%$ of infants born to mothers who are positive for $\mathrm{HBsAg}$ and $\mathrm{HBeAg}$, become chronic carriers [17,46,62]. Hepatitis $C$ virus is a single-stranded RNA virus, it is transmitted also through infected blood, sexually and vertically $[21,47,73]$. HCV has a long lag time between onset of infection and clinical manifestation of liver disease (up to 20 years) [52]. Chronic active hepatitis $\mathrm{C}$ infection is associated with increased incidence of preterm delivery and intra-uterine growth retardation [77]. Vertical transmission of HCV from mother to child occurs in $3-10 \%$ of pregnancies complicated by HCV infection [14]. Among pregnant women, chronic infection with $\mathrm{HBV}$ and $\mathrm{HCV}$ are often asymptomatic, and can lead to coagulation defects, postpartum haemorrhage, organ failure and high maternal mortality and poor outcomes of their newborns such as still births, neonatal deaths (NND), jaundice, anorexia (poor appetite), malaise, acute and chronic liver disease (liver cirrhosis) and hepatocellular 
carcinoma. Maternal mortality has been shown to increase in pregnant women with liver cirrhosis [48]. Peri-natal transmission of this disease occurs if the mother has had acute Hepatitis B infection during late pregnancy, in the first postpartum or if the mother is a chronic HBsAg carrier [39]. The prevalence of HBV infection in Nigeria was estimated to be $2.4-18.4 \%$ of the population $[53,58,71]$. Also, the sero-prevalence of anti-HCV was $3.6 \%$ to $5 \%$ in previous studies in Nigeria [22,70]. This study was therefore designed to determine the seroprevalence of Hepatitis $\mathrm{B}$ and $\mathrm{C}$ virus infections among apparently healthy pregnant women.

\section{Materials and Methods}

Apparently 649 healthy pregnant women who attended the antenatal clinic of the Federal Medical Centre IdoEkiti, Ekiti State, Nigeria from February 2012 to September 2013 were recruited for the study after obtained their consent. $4 \mathrm{ml}$ of venous blood was collected by venepuncture into a plain bottle and allowed to clot. The presence of Hepatitis B surface antigen (HBsAg) and Presence of antibodies against HCV (anti-HCV) was determined using third-generation enzyme immunoassay (EIA), rapid test ELISA kits (Acon Laboratories, USA); reactive samples were further confirmed using enzyme linked immune sorbent assay (ELISA) (Bio-Rad, France), the procedures were described by the manufacturer of the kit. An ethical clearance for this study was obtained from ethical and research committee.

Table 1. Age disribution and prevalence of $\mathrm{HBV}$ among pregnant women

\begin{tabular}{|l|l|l|}
\hline $\begin{array}{l}\text { Age } \\
\text { group }\end{array}$ & $\begin{array}{l}\text { No of samples screened for } \\
\text { HBV }\end{array}$ & $\begin{array}{l}\text { HBV Sero- } \\
\text { positivity }\end{array}$ \\
\hline $15-20$ & $15(2.31 \%)$ & $2(4.55 \%)$ \\
\hline $21-25$ & $75(11.56 \%)$ & $7(15.91 \%)$ \\
\hline $26-30$ & $240(36.98 \%)$ & $11(25.00 \%)$ \\
\hline $31-35$ & $206(31.74 \%)$ & $16(36.36 \%)$ \\
\hline $36-40$ & $86(13.25 \%)$ & $5(11.36 \%)$ \\
\hline $41-$ above & $27(4.16 \%)$ & $3(6.82 \%)$ \\
\hline Total & $649(100 \%)$ & $44(100 \%)$ \\
\hline
\end{tabular}

\section{Results}

Apparently 649 health pregnant women within the age group 15-41 above between February 2012 and September 2013 were recruited for this study from Federal Medical Centre, Ido-Ekiti. Age group 26-30 and 31-35 had highest frequency 240 (36.98\%) and 206 (31.74\%) respectively in HBV and HCV while age group 15-20 and 41-above had lowest frequency 15 (2.31\%) and 27 (4.16\%) respectively in HBV and HCV. Sero prevalence of hepatitis B virus (HBV) and hepatitis C virus (HCV) were 44 (6.78\%) and 9 (1.39\%) respectively. Age group 26-30 and 31-35 had highest prevalence of HBV and HCV as showed in Table
1 and Table 2. Prevalence of HBV and HCV co-infection was $1(0.15 \%)$ in age group $31-35$ as showed in Table 3.

Table 2. Age disribution and prevalence of $\mathrm{HBV}$ among pregnant women

\begin{tabular}{|l|l|l|}
\hline $\begin{array}{l}\text { Age } \\
\text { group }\end{array}$ & $\begin{array}{l}\text { No of samples screened for } \\
\text { HCV }\end{array}$ & $\begin{array}{l}\text { HCV Sero- } \\
\text { positivity }\end{array}$ \\
\hline $15-20$ & $15(2.31 \%)$ & - \\
\hline $21-25$ & $75(11.56 \%)$ & - \\
\hline $26-30$ & $240(36.98 \%)$ & $2(22.22 \%)$ \\
\hline $31-35$ & $206(31.74 \%)$ & $6(66.67 \%)$ \\
\hline $36-40$ & $86(13.25 \%)$ & $1(11.11 \%)$ \\
\hline 41 -above & $27(4.16 \%)$ & - \\
\hline Total & $649(100 \%)$ & $9(100 \%)$ \\
\hline
\end{tabular}

Table 3. Age disribution and prevalence of HBV, HCV CO-Infection among pregnant women

\begin{tabular}{|l|l|l|l|}
\hline $\begin{array}{l}\text { Age } \\
\text { group }\end{array}$ & $\begin{array}{l}\text { No of samples } \\
\text { screened for HBV } \\
\text { and HCV }\end{array}$ & $\begin{array}{l}\text { No of HBV and } \\
\text { HCV positivity }\end{array}$ & $\begin{array}{l}\text { No of HBV and } \\
\text { HCV co- } \\
\text { infection }\end{array}$ \\
\hline $15-20$ & $15(2.31 \%)$ & $2(3.77 \%)$ & - \\
\hline $21-25$ & $75(11.56 \%)$ & $7(13.21 \%)$ & - \\
\hline $26-30$ & $240(36.98 \%)$ & $13(24.53 \%)$ & - \\
\hline $31-35$ & $206(31.74 \%)$ & $22(41.51 \%)$ & $1(0.15 \%)$ \\
\hline $36-40$ & $86(13.25 \%)$ & $6(11.32 \%)$ & - \\
\hline $41-$ & $27(4.16 \%)$ & $3(5.66 \%)$ & - \\
\hline above & & $53(100 \%)$ & 1 \\
\hline Total & $649(100 \%)$ & & \\
\hline
\end{tabular}

\section{Discussion}

Infections due to Hepatitis $\mathrm{B}$ and Hepatitis $\mathrm{C}$ viruses (HBV, HCV) are significant health problems around the globe. Worldwide, viral hepatitis is the commonest cause of hepatic dysfunction in pregnancy. The prevalence of HBV varies between $2 \%$ in developed countries where the prevalence is low to about $8 \%$ in developing countries where infection is endemic with sex, age and socioeconomic status as important risk factors for infection $[5,27,56]$. Countries are classified as having low endemic rates $(<2 \%)$, intermediate endemic rates $(2-8 \%)$, or high endemic rates $(>8 \%)$ positive for $\mathrm{HBV}$. In our study, the frequency of Hepatitis B and Hepatitis C infections among pregnant woman attending the Federal Medical Centre, Ido-Ekiti were $6.78 \%$ and $1.39 \%$ respectively while $0.15 \%$ was recorded for both $\mathrm{HBV}$ and HCV co-infection. Prevalence of $6.78 \%$ and $1.39 \%$ for $\mathrm{HBV}$ and $\mathrm{HCV}$ respectively in this present study was supported by WHO's report for Nigeria, with prevalence of $\mathrm{HBV}$ and $\mathrm{HCV}$ greater than $8 \%$ and $1.2 \%$ respectively [76]. Previous studies on prevalence of HBV done in Southeast Nigeria reported (2.2\%) [51], Obi reported 
(2.9\%) in the South-South Nigeria, Studies from the Middle East reported 4.3\% of HBV in Jordan [10] and 2.4\% in Saudi Arabia [34] which were lower compared to this present study. However studies from the Northerneast Nigeria by Olokoba reported (8.2\%), Ali reported 8.0\% seroprevalence of Hepatitis B in pregnant women; $8.3 \%$ to $12.5 \%$ was reported by other workers in Nigeria $[27,70]$. A study conducted in Abidiajan, Ivory Coast Africa show 8.5\% prevalence of $\mathrm{HBV}$ [63], 7.3\% prevalence of $\mathrm{HBV}$ among pregnant women in Kano as reported by Dawaki, also $5.6 \%$ of HBV in Sudan was reported by Elsheikh et al., 2007 among pregnant women which was almost similar to the prevalence in this present study. The seroprevalence of $\mathrm{HBV}$ finding in this study is in agreement with the previous studies done among pregnant women in Addis Ababa (5.0\%), and Jimma, Ethiopia (1.4\%-6.4\%) (Tsega et al., 1988; Awole and GebreSelassie, 2005). Sierra Leone (6.2\%), Zambia (6.5\%), USA, only for Asian Americans (5.6\%), Jeju Island of Korea (4.9\%-6.4\%), and Turkey (4.2\%) $[26,32,38,55,59,60]$. In the North Central Mbaawuga reported $(11.0 \%)$ also $18.2 \%$ was reported in Zaria by Luka et al., 2008 which was higher compared to this present study. Africa is considered to be a high prevalent zone for Hepatitis $\mathrm{B}$, higher prevalence rates were reported from Ghana 10.5\% [20] and Yemen 13.2\% [7]. In United States, the prevalence of Hepatitis B and Hepatitis $\mathrm{C}$ is found to be 0.5 to $1.5 \%$ and $1 \%$ respectively [51]. Prevalence of HBV in this study shows an intermediate endemicity of HBV infection according to WHO criteria [75]. However, there are reports from other parts of the world showed a low prevalence in the same study population, a prevalence of $0.14 \%-0.97 \%$ in USA, except Asian Americans, in Mexico (1.65\%), in the northern part of Kerala state in South India (0.21\%), Qatar and the United Arab Emirates (1.0-1.5\%) were reported [6,26,62,72]. A higher prevalence was found among a similar study population in Mali (15.5\%), Hong Kong (10.0\%), Papa New Guinea (11.0\%), Taiwan (12.0\%), Oman (7.1\%) and in Brazil (18.5\%, ranging from 7.2\%$38.5 \%)$ [6,12,18,37,40,64]. Comparison of our result with other studies from different countries on pregnant women showed a variable result. The difference in demographic characteristics of the study population such as sociocultural environment, tribal practices, traditional operation, sexual practices, medical exposure and the difference in hepatitis epidemiology in these countries might explain these discrepancies. Prevalence of HCV in this study was higher than the 0.5\% recorded by Buseri et al., 2010 among pregnant women in Yenagoa, Bayelsa state, Nigeria. $1.5 \%$ of HCV seropositivity in pregnant women attending the University of Abuja teaching hospital, Gwagwalada, Nigeria [8,15] was similar to prevalence of HCV in this present study, also 1.03\% observed by Kumar et al., 2007 in India was similar to prevalence of HCV this present study. $1.39 \%$ of HCV obtained in this study was lower than $3.6 \%$ recorded by Ugbebor in a study conducted among pregnant women attending the antenatal clinic of the University of Benin teaching hospital. 5\% and $14.9 \%$ have been recorded in faith me diplex hospital in Benin City and in Enugu, Nigeria [22,65,70] and 2.1\% in Gabon (Ndong-Atome et al., 2008). Batool et al., 2008 reported $7.3 \%$ for anti HCV which was much higher compared to $1.39 \%$ of $\mathrm{HCV}$ in this present study he also reported $2.2 \%$ for HBV and $0.08 \%$ for HBV and HCV coinfection which was lower compared to prevalence in this present study [24]. Elsheikh reported 5.6\% for $\mathrm{HBV}$ and $0.6 \%$ for Anti-HCV which was lower compared to the prevalence reported in this study; also stated that none of the participants were aware of their condition and age, parity, gestational age, residence, history of blood transfusion, dental manipulations, tattooing and circumcision did not contribute significantly to increased HBV sero-positivity [24]. This difference may be as a result of the type of population studied, different geographical regions, genetic factors and socioeconomic status, also regional differences in risk factors and cultural practices may be responsible for these variations in prevalence rates. Sero-epidemiological studies of different populations show marked variations and differences. The age of acquiring infection is the major determinant of the incidence and prevalence rates [27]. In this study it was found that most of the patients fell within the age group 26-30 and 31-35 because these were the majority age groups attended antenatal clinic of the hospital. Mortada et al., 2013 reported that HBV was detected at a higher rate in pregnant women aged greater than 25 years than in women aged less than 25 years, the difference was not statistically significant. Habiba and Memon 2007 from Pakistan also reported that the majority of those that tested positive to HBV were in the age range 25-35 years which was similar to this present study. Other studies also observed a high prevalence rate of $\mathrm{HBV}$ in pregnant women greater than 25 years than those less than 25 years $[25,66]$. The increased age among HBV positive mothers may be due to increase the chance of exposure to HBV and HCV for each pregnancy. However, Eke et al., 2011 reported a highest prevalence of HBV among pregnant women whose age ranged 20-24 years. The authors attributed that difference to the early marriage and pregnancy of women in South-Eastern Nigeria. Hence, those positive to $\mathrm{HBV}$ are likely to be picked when screened during their antenatal care. Pregnant women are considered at a higher risk due to increased exposure to risk factors (such as blood transfusion, intravenous drugs or surgical procedures) [13]. In our study most of the patients were found to be multi gravida patients. Azhar et al., 2012 reported a higher frequency of HBV infection among multigravidae. It might be at increased risk of $\mathrm{HBV}$ and HCV infection among multigravidae because of their past pregnancies, hospital admission blood transfusion and/or any surgical procedure in the past [33]. Therefore, with each pregnancy and childbirth chances of exposure to $\mathrm{HBV}$ and $\mathrm{HCV}$ become greater. Rural residence could also be a risk factor for $\mathrm{HBV}$ and $\mathrm{HCV}$ infection, socioeconomic conditions among the poor and less educated, and crowded living condition especially in the rural areas, may contribute to $\mathrm{HBV}$ and $\mathrm{HCV}$ exposure [16,29].

\section{Conclusion}

Proper management of maternal hepatitis during the prenatal phase ensures better outcomes in the infant, therefore screening of pregnant women for hepatitis B and $C$ virus are highly necessary in order to identify those neonates at risk of transmission, to whom preventive 
intervention can be instituted irrespective of maternal hepatitis $\mathrm{B}$ and $\mathrm{C}$ virus carriage status; this may be the most effective approach to hepatitis $B$ and $C$ virus prevention and control.

\section{Recommedation}

Pregnant woman should be mandatorily and routinely screened for hepatitis B and C virus infection as part of antenatal care services in their booking; also infants and new borns must be systematically immunized against hepatitis $\mathrm{B}$ and $\mathrm{C}$ virus infection. Public awareness, complete immunization against viral hepatitis, better sanitation facilities, safe drinking water, increased availability of antenatal care for early detection and well equipped hospitals for intensive care will go long way in the reduction of viral hepatitis in pregnancy and also its associated maternal and per-natal mortality and morbidity.

\section{References}

[1] Abildgaard N, Peterslund NA (1991). Hepatitis C virus transmitted by tattooing needle. Lancet; 338: 460.

[2] Agarry OO, Zamani GL. Prevalence of Hepatitis B virus and hepatitis $C$ in antenatal patients in Gwagwalada-Abuja, Nigeria.

[3] Akbar N, Basuki B, Mulyanto, Garabrant DH, Sulaiman A, Noer HM (1997). Ethnicity, Socioeconomic status, transfusions and risk of hepatitis B and C infection. J Gastroenterol Hepatol; 12: 752757.

[4] Ahmedin J, Taylor M, Ram CT, et al., 2004 A New Section in Cancer Offering Timely and Targeted information, Can J Clin.; 54: 23-25.

[5] Alikor EA and Erhabor ON (2007). Seroprevalence of hepatitis B surface antigenaemia in children in a tertiary health institution in the Niger delta of Nigeria. Niger J Med.; 16: 250-251.

[6] Al Awaidy S, Abu-Elyazeed R, Al Hosani H, et al., 2006 Seroepidemilogy of hepatitis B Infection in pregnant women in Oman, Qatar and the United Arab Emirates. J infect; 52 (3): 202-206.

[7] Al-Shamahy HA (2000). Prevalence of hepatitis B surface antigen and risk factors of HBV infection in a sample of healthy mothers and their infants in Sana'a, Yemen. Ann Saudi Med; 20: 464-467.

[8] Awole M, Gebre-Selassie S (2005). Seroprevalence of HBsAg and its risk factors among pregnant women in Jimma, Southwest Ethiopia. Ethiop J Health Dev; 19 (1): 45-50.

[9] Azhar T, Khan IA, Mohsein S, Usman J (2012). Antenatal screening for hepatitis $\mathrm{B}$ and $\mathrm{C}$ virus infection in pregnant women in a tertiary care hospital of Rawalpindi. Available on line at: http://www.pafmj.org, 2011.

[10] Batayneh N, Bdour S (2002). Risk of perinatal transmission of hepatitis B virus in Jordan. Infect Dis Obster Gynaecol; 10: 127132.

[11] Batool A, Bano KA, Khan MU, Hussain R (2008). Antenatal screening of women for Hepatitis $\mathrm{B}$ and $\mathrm{C}$ in an outpatient department. J Dow Univers Health Sci.; 2: 32-35.

[12] Bertolini DA, Pinho JRR, Saraceni CP, et al., 2006 Prevalence of serological markers of hepatitis $B$ virus in pregnant women from Parana state, Brazil. Braz J Med Bio Res; 39 (8): 1083-1090.

[13] Beasley RP, Hwang LY, Lee GC, Lan CC, Roan CH, Huang FY (1983). Prevention of perinatally transmitted hepatitis B virus infections with hepatitis B immune globulin and hepatitis B vaccine. Lancet; 2: 1099-1102.

[14] Berkley EMF, Leslie KK, Arora S, Qualls C, Dunkelberg JC (2008). Chronic Hepatitis C in Pregnancy. Obstet. Gynecol. 112: 304-310.

[15] Buseri FI, Seiyabo E, Jeremiah ZA (2010). Surveying infections among pregnant women in the Niger Delta, Nigeria. J. Global Infect Dis.; 2: 203-211.

[16] Bwogi J, Braka F, Makumbi I, Mishra V, Bakamutumaho B, Nanyunja M, Opio A, Downing R, Biryahwaho B, Lewis RF (2009). Hepatitis B infection is highly endemic in Uganda: findings from a national serosurvey. Afr Health Sci.; 9: 98-108.
[17] Chang MH (2000). Natural history of hepatitis B virus infection in children. J. Gastroenterol. Hepatol. 15: 16-19.

[18] Clegg T (1991). Hepatitis B surface and e antigen seropostivity in mothers and cord blood at Port Moresby General Hospital: Implication for a control program. Papua New Guinea Med J; 34: 234-237.

[19] Dawaki SS, Kawo AH (2006). Seroprevalence of Hepatitis B surface antigen (HBsAg) in pregnant women attending an urban maternity hospital in Kano, Nigeria. Nig J Microbial.; 20: 705-709.

[20] Damale NKR, Lassey AT, Bekoe V (2005). Hepatitis B virus seroprevalence among paturients in Accra, Ghana. Inter J Gynecol and Obstet; 90: 240-241.

[21] Dienstag JL (1983). Non-A, non-B hepatitis I. Recognition, epidemiology, and clinical features. Gastroenterol. 85: 439-462.

[22] Duru MU, Aluyi HAS, Anukam KC (2009). Rapid screening for co-infection of HIV and HCV In pregnant women in Benin City, Edo state, Nigeria. Afr Health Sci.; 9: 137-142.

[23] Eke AC, Eke UA, Okafor CI, Ezebialu IU, Ogbuagu A (2011). Prevalence, correlates and pattern of hepatitis B surface antigen in a low resource setting. Virol J; 8: 12.

[24] Elsheikh R, Daak A, Elsheikh M, Karsany M, Adam I (2007). Hepatitis B virus and hepatitis C virus in pregnant Sudanese women. Virol. J. 4 (1): 104.

[25] El-Magrahe H, Furarah AR, El-Figih K, El-Urshfany S, Ghenghesh KS (2010). Maternal and neonatal seroprevalence of Hepatitis B surface antigen (HBsAg) in Tripoli, Libya. J Infect Dev Ctries; 4: 168-170.

[26] Euler GL, Wooten KG, Baughman AL, et al., 2003. Hepatitis B surface antigen prevalence among pregnant women in urban areas: implications for testing, reporting, and preventing perinatal transmission. Pediatrics; 111 (5 part 2): 1192-1197.

[27] Ezegbudo CN, Agbonlahor DE, Nwobu GO, Igwe CU, Agba MI, Okpala HO, Ikaraoha CI (2004). The seroprevalence of hepatitis B surface antigen and Human Immunodeficiency Virus among pregnant women in Anambra state, Nigeria. Shiraz E-medical Journal; 5: 1-25.

[28] Goldstein ST, Zhou F, Hadler SC, Bell BP, Mast EE, Margolis HS (2005). A mathematical model to estimate global hepatitis B disease burden and vaccination impact. Int. J. Epidemiol. 34: 1329-1339.

[29] Gray Davis L, Weber DJ, Lemon SM (1989). Horizontal transmission of hepatitis B virus. Lancet; 1: 889-893.

[30] Habiba SA, Memon MA (2007). Prevalence of Hepatitis B infection in pregnant women in a tertiary care hospital. Infectious Disease Journal of Pakistan; 35-38.

[31] Haider Z, Khan AA, Rehman K, Janjua MI, Iqbal J, Chishti MA, et al., 1994 Sero-diagnosis of Viral hepatitis in 93 patients admitted with acute hepatitis in three different teaching hospitals in Lahore. J Pak Med Assoc; 44: 182-4.

[32] Kang HS, Song BC, Ji CX, et al., 2004 Serologic markers of hepatitis B virus in pregnant women in Jeju island. Korean $J$ Hepatol; 10 (3): 191-196.

[33] Khattak ST, Ali Marwat M, Khattak ID, Khan TM, Naheed T (2009). Comparison of frequency of hepatitis $b$ and hepatitis $c$ in pregnant women in urban and rural area of district Swat. $J$ Ayub Med Coll Abbottabad; 21: 12-15.

[34] Khalil MKM, Al-Mazrou YY, Al-Jeffri M, Al-Ghamdi YS, Mishkhas A, Bakhsh M, Eisa M, Nageeb M, Tumash S (2005). Seroprevalence of hepatitis B surface antigen in pregnant Saudi women. Eastern Mediterran Health J; 11: 640-647.

[35] Kumar A, Sharma KA, Gupta RK, Kar P, Chakravarti A (2007). Prevalence and risk factors for hepatitis $\mathrm{C}$ virus among pregnant women. Ind. J. Med. Res. 126: 211-215.

[36] Kramvis A, Kew M (2007). Epidemiology of hepatitis B virus in Africa, its genotypes and clinical associations of genotypes Hepatol. Res. 37 (Supplement 1): 9-19.

[37] Kwan LC, Cho Y, Lee SS (1997). The declining HBsAg carriage rate in pregnant women in Hong Kong. Epidemiol Infect; 119 (2): 281-283.

[38] Kuru U, Turan O, Kuru N, et al., 1996 Prevalence of hepatitis B virus infection in pregnant Turkish women and their families. Eur Clinical Microbiol Iinfect Dis; 15 (3): 248-251.

[39] Levy M, Koren G (1991). Hepatitis B vaccine in pregnancy: Maternal and fetal safety. Am J Perinatol; 8: 227-232.

[40] Lin HH, Kao JH, Chang TC, et al., 2003. Secular trend of age specific prevalence of hepatitis B Surface and e antigenemia in pregnant in Taiwan. J Med Virol; 69 (4):66-470. 
[41] Luby SP, Qamruddin K, Shah AA, Omair A, Pahsa O, Khan AJ, et $a l$, 1997. The relationship between therapeutic injections and high prevalence of hepatitis C infection in Hafizabad, Pakistan. Epidemiol Infect; 119: 349-356.

[42] Luka SA, Ibrahim MB, Iliya S (2008). Seroprevalence of Hepatitis $B$ surface antigen among pregnant women attending antenatal clinic in Ahmadu Bello University Teaching Hospital Zaria. Nig. J. Parasitology.

[43] Madhava V, Burgess C, Drucker E (2002). Epidemiology of chronic hepatitis C virus infection in sub-Saharan Africa. Lancet. Infect. Dis. 2: 293-302.

[44] Mbaawuga EM, Enenebeaku MNO, Okopi JA, Damen JG (2008). Hepatitis B virus (HBV) infection among pregnant women in Markudi, Nigeria. Af J Biomed R; 11: 155-159.

[45] Mbamara SU, Obiechina N (2010). Seroprevalence of hepatitis B surface antigen among antenatal clinic attendees in a private specialist hospital in Onitsha, Southeast Nigeria. Niger Med J; 51: 152-154.

[46] McMahon BJ, Alward WLM, Hall DB, Heyward WL, Bender TR, Francis DP, Maynard JE (1985). Acute Hepatitis B Virus Infection: Relation of Age to the Clinical Expression of Disease and Subsequent Development of the Carrier State. J. Infect. Dis. 151 (4): 599-603.

[47] Melbye M, Biggar RJ, Wantzin P, Krogsgaard K, Ebbesen P, Becker NG (1990). Sexual transmission of hepatitis C virus: cohort study (1981-9) among European homosexual men. BMJ. 301 (6745): 210-212.

[48] Mishra L, Seeff LB (1992). Viral hepatitis, A though E, complicating pregnancy. Gastroenterol. Clin. North Am. 21 (4): 873-887.

[49] Mortada EL-Shabrawi, Mohamed Farouk Mohamed, Mona Salah El Din Hamdi, Mohamed Ehab, Shaimaa Shaaban Khamiss and Hanaa El-Karaksy (2013). Prevalence of Hepatitis B Virus Infection among Egyptian Pregnant Women-A Single Center Study; International Journal of Tropical Disease \& Health 3 (2): 157-168.

[50] Mujeeb SA. Seroprevalence and pattern of viral hepatitis in Pakistan. Infect Dis J 1998; 5: 20-21.

[51] Munoz.PS, Robert. S, Sheffiedld. J et al 6.3\% Prevalence of hepatitis B and C in pregnant women who are infected with HIV. American Journal of Obstetrics and Gynecology Vol 2005; 193, (3) Supplement 1, September: 1270-3.

[52] National Institute of Health (2002). Management of Hepatitis C. NIH Consensus Development Program: 19: 1-35.

[53] Ndako JA, Nwankiti OO, Echeonwu GON, Junaid SA, Anaele O, Anthony TJ (2011). Studies on Prevalence and Risk Factors for Hepatitis B Surface Antigen among Secondary School Students in North-central, Nigeria. Sierra Leone J. Biomedical Res. 3 (3): 163168.

[54] Ndong-Atome GR, Makuwa M, Njouom R, Branger M, BrunVezinet F, Mahe A, Rousset D, Kazanji M (2008). Hepatitis C virus prevalence and genetic diversity among pregnant women in Gabon, central Africa. BMC Infect. Dis. 8 (1): 82.

[55] Obi SN, Onah HE, Ezugwu FO (2006). Risk factors for hepatitis B infection during pregnancy in a Nigerian Obstetric population. $J$ Obstet Gynaecol; 26 (8): 770-772.

[56] Odusanya OO, Alufohai FE, Meurice FP, Wellens R, Weil J, Ahonkhai VI (2005). Prevalence of hepatitis B surface antigen in vaccinated children and controls in rural Nigeria. International $J$ Infect Dis; 9: 139-143.

[57] Oliveira ML, Bastes FI, Telles PR, Yoshida CF, Schatzmayr HG, Paetzold U, et al., 1999 Prevalence and risk factors for HBV, HCV and HDV infections among injecting drug users. Braz J Med Biot Res; 32: 1107-1114.
[58] Olokoba AB, Salawu FK, Danburam A, Desalu OO, Olokoba LB, Wahab KW, Badung LH, Tidi SK, Midala J, Aderibigbe S, Abdulrahman MB, Babalola OM, Abdukkarim A (2009). Viral Hepatities in Voluntary Blood Donors in Yola, Nigeria. Euro. $J$. Scientific Res. 31 (3): 329-334.

[59] Ojule AC, Akani CI, Opurum HC, et al., 2005 Seroprevaence of hepatitis B surface antigen (HBsAg) in pregnant women in Port Harcourt, Nigeria. Niger Postgrad Med J; 12 (4): 266-270.

[60] Oshitani H, Kasoslo C, Tembo M, et al., 1995. Hepatitis B virus infection among pregnant women in Zambia. East Afri Med J; 72 (12): 813-815.

[61] Roy KM, Goldberg D, Taylor A, Mills P (2003). Investigating the source of hepatitis $C$ virus Infection among individuals whose route of infection is undefined: a study of ten cases. Scand J Infect Dis; 35: 326-328.

[62] Sandesh K, Varghese T, Harikumar R, et al., 2006. Prevalence of hepatitis $\mathrm{B}$ and $\mathrm{C}$ in the normal population and high-risk groups in north Kerala. Trop Gastroenterol; 27 (2): 80-83.

[63] Sellati M P, Inwoley, A claix Ml et al 2003. Prevalence of Hepatitis $\mathrm{B} / \mathrm{C}$ virus and HCV genotypes in HIV positive and negative women in Abidjan, Ivory coast West Africa, 8 (1): 974.

[64] Sidibe S, Sacko BY and Traore I (2001). Prevalence of serologic markers of the Hepatitis B virus In pregnant women of Bamako, Mali. Bull Soc Pathol Exot; 94 (4): 339-341.

[65] Strickland GT (2002). HCV in developing countries. Postgrad Doc (Africa); 24: 18-20.

[66] Taseer IU, Ishaq F, Hussain L, Safdar S, Mirbahar AM, Faiz SA (2010). Frequency of anti-HCV, HBsAg and related risk factors in pregnant women at Nishtar Hospital, Multan. J Ayub Med Coll Abbottabad; 22: 13-16.

[67] Tassopoulos NC, Papaevangelou GJ, Sjogren MH, RoumeliotouKarayannis A, Gerin JL, Purcell RH (1987). Natural history of acute hepatitis B surface antigen-positive hepatitis in Greek adults. Gastroenterol. 92 (6): 1844-1850.

[68] Tran TT (2009). Understanding cultural barriers in hepatitis B virus infection. Cleveland Clin. J. Med. 76 (Suppl 3): 10-13.

[69] Tsega E, Tsega M, Mengesha B, et al., 1988 Transmission of hepatitis B virus infection in Ethiopia with emphasis on the importance of vertical transmission. Int J Epidemiol; 17 (4): 874879.

[70] Ugbebor O, Aigbirior M, Osazuwa F, Enabudoso E, Zabayo O (2011). The prevalence of hepatitis B and C viral infections among pregnant women. North Am. J. Med. Sci. 3 (5): 238-241.

[71] Ugwuja EI, Ugwu NC (2010). Seroprevalence of Hepatitis B Surface Antigen and Liver Function Tests among Adolescents in Abakaliki, South Eastern Nigeria. The Internet J. Trop. Med. 6 (2): 1-6.

[72] Vazquez-Martinez JL, Coreno-Juarez MO, Montano-Estrada LF, et al., 2003 Seroporevalence of hepatitis in pregnant women in Mexico, Salud publica Mex; 45 (3): 165-170.

[73] Wejstal R, Widell A, Mansson A, Hermodsson S, Norkrans G (1992). Mother-to Infant Transmission of Hepatitis C Virus. Ann. Internal Med. 117 (11): 887-890.

[74] World Health Organization. (2011). Factsheet No 164.

[75] WHO/EPI (1990). Protocol for assessing prevalence of hepatitis B infection in antenatal patients. WHO/EPI/GEN/90.6 1990.

[76] World Health Organization (1999). Global surveillance and control of hepatitis C. Report of a WHO Consultation organized in collaboration with the Viral Hepatitis Prevention Board. JVH; 6: 35-47.

[77] Zanetti AR, Tanzi E, Newell ML (1999). Mother-to-infant transmission of hepatitis C virus.J.Hepatol. 31: 96-100. 